\title{
Actin and DNA Protect Histones from Degradation by Bacterial Proteases but Inhibit Their Antimicrobial Activity
}

\author{
Asaf Sol' ${ }^{1 * 1}$, Yaniv Skvirsky ${ }^{1}$, Edna Blotnick ${ }^{2}$, Gilad Bachrach ${ }^{1}$ and Andras Muhlrad ${ }^{1}$ \\ ${ }^{1}$ Institute of Dental Sciences, Hebrew University-Hadassah School of Dental Medicine, Jerusalem, Israel, ${ }^{2}$ Department of \\ Medical Neurobiology, Institute for Medical Research-Israel-Canada, Hebrew University of Jerusalem, Jerusalem, Israel
}

OPEN ACCESS

Edited by:

Yuji Morita,

Aichi Gakuin University, Japan

Reviewed by:

Shawn Lewenza,

Athabasca University, Canada

Mary Ellen Davey,

University of Florida, USA

Marco Scocchi,

University of Trieste, Italy

*Correspondence:

Asaf Sol

asaf.so/@tufts.edu

${ }^{\dagger}$ Present address:

Asaf Sol,

Department of Molecular Biology and Microbiology, Tufts University,

Boston, MA, USA

Specialty section:

This article was submitted to Antimicrobials, Resistance

and Chemotherapy,

a section of the journal

Frontiers in Microbiology

Received: 15 March 2016

Accepted: 27 July 2016

Published: 09 August 2016

Citation:

Sol A, Skvirsky Y, Blotnick E, Bachrach $G$ and Muhlrad A (2016)

Actin and DNA Protect Histones

from Degradation by Bacterial

Proteases but Inhibit Their

Antimicrobial Activity.

Front. Microbiol. 7:1248.

doi: 10.3389/fmicb.2016.01248
Histones are small polycationic proteins located in the cell nucleus. Together, DNA and histones are integral constituents of the nucleosomes. Upon apoptosis, necrosis, and infection - induced cell death, histones are released from the cell. The extracellular histones have strong antimicrobial activity but are also cytotoxic and thought as mediators of cell death in sepsis. The antimicrobial activity of the cationic extracellular histones is inhibited by the polyanionic DNA and F-actin, which also become extracellular upon cell death. DNA and F-actin protect histones from degradation by the proteases of Pseudomonas aeruginosa and Porphyromonas gingivalis. However, though the integrity of the histones is protected, the activity of histones as antibacterial agents is lost. The inhibition of the histone's antibacterial activity and their protection from proteolysis by DNA and F-actin indicate a tight electrostatic interaction between the positively charged histones and negatively charged DNA and F-actin, which may have physiological significance in maintaining the equilibrium between the beneficial antimicrobial activity of extracellular histones and their cytotoxic effects.

Keywords: histone, DNA, proteases, sepsis, cationic peptides, actins, antimicrobial peptides

\section{INTRODUCTION}

Histones are highly positively charged polypeptides located in the cell nucleus of eukaryotes. They are the major protein component of chromatin where they spool around DNA and playing an important role in gene regulation (Williamson and Pinto, 2012). There are five major families of histones: $\mathrm{H} 1, \mathrm{H} 2 \mathrm{~A}, \mathrm{H} 2 \mathrm{~B}, \mathrm{H} 3$, and $\mathrm{H} 4$. While histones $\mathrm{H} 2 \mathrm{~A}, \mathrm{H} 2 \mathrm{~B}, \mathrm{H} 3$, and $\mathrm{H} 4$ are core histones, histone $\mathrm{H} 1$ and its $\mathrm{H} 5$ derivative are linker histones. The core histones all exist as dimers, they all possess the histone fold domain; three alpha helices linked by two loops. $\mathrm{H} 1, \mathrm{H} 2 \mathrm{~A}$, and H2B histones are rich in lysine and $\mathrm{H} 3$ and $\mathrm{H} 4$ are rich in arginine (Tagai et al., 2011). Histones are released from neutrophils and from dead cells following apoptosis (Chaput and Zychlinsky, 2009). Upon inflammation, extracellular histones are found in neutrophils extracellular traps (NETs) together with other proteins and DNA (Brinkmann et al., 2004). Histones are separated from DNA and released also during apoptosis (Wu et al., 2002; Wickman et al., 2013) and necrosis (Chen et al., 2014). Histones including H2A (Sathyan et al., 2013), H2B (Robinette et al., 1998; Kawasaki and Iwamuro, 2008; Kawasaki et al., 2008), H4 (Lee et al., 2009), and H1 (Richards et al., 2001) have antimicrobial activity (Katchalski et al., 1952; Hirsch, 1958). They have an important 
role in protecting skin of vertebrates from bacterial infections. Their smaller derivatives, such as buforin which is a derivative of the H2A histone (Lee et al., 2008; Cho et al., 2009), have higher antimicrobial activity and are essential for protecting the integrity of frog's stomach endothelium. These small histonederived peptides also possess anti-endotoxin and anticancer activities (Jang et al., 2011), thus making them attractive reagents for pharmaceutical applications (Cho et al., 2009). However, extracellular histones have also a deleterious side (Xu et al., 2015) since they can act as inflammatory agents synergistically with other secreted compounds (Ginsburg et al., 1993; Koren and Ginsburg, 2015). They may cause several deleterious effects such as endothelial and renal dysfunction, and are major mediators of death in sepsis (Xu et al., 2009). In general, extracellular histones have a significant role in tissue injury and inflammation (Allam et al., 2014).

Actin is a negatively - charged structural protein, which is the most abundant protein in the eukaryotic cell. It has an important role in cytoskeleton formation, cell division, motility, adhesion, signaling, and more (Rottner and Stradal, 2011). Actin exists in either monomer globular $(G)$ or polymer- filament (F) forms, which are interconvertible into each other. Actin interacts with positively charged proteins and peptides, such as lysozyme (Muhlrad et al., 2011) and LL-37 (Sol et al., 2012), which polymerize $\mathrm{G}$-actin to F-actin and bundle F-actin filaments. F-actin protects LL-37 from proteolysis by bacterial proteases and enables its antibacterial activity in their presence (Sol et al., 2014). H1 histone was shown to polymerize G-actin (Magri et al., 1978) and histone H2A-H2B dimer was demonstrated to bundle F-actin (Doyle et al., 2011). Histones bind very tightly to the negatively charged DNA, and form together with DNA highly structured nucleosomes in the cell nucleus. Significant amount of DNA are released from cells following NETosis (Chen et al., 2014) and apoptosis (Williamson and Pinto, 2012). Here we studied the interaction of an extracellular histone mixture with F-actin and DNA. The effect of F-actin and DNA on the antimicrobial activity of the histone mixture and on its proteolysis by bacterial proteases were investigated. We found that both F-actin and DNA protect histone from proteolytic degradation but at a cost of inhibiting the histones antimicrobial action.

\section{MATERIALS AND METHODS}

\section{Materials}

ATP, ADP, dithiotreitol (DTT), histone type III (histone mixture) and deoxyribonucleic acid (DNA) from calf thymus were purchased from Sigma Chemical Co. (St Louis, MO, USA). Acetone dry powder from back and leg muscles of rabbit was purchased from Pel-freeze Biologicals (Rogers, AR, USA).

\section{Preparation of Actin}

CaATP-G-actin was prepared from acetone dried powder derived from the back and leg muscles of rabbit by the method of Spudich and Watt (1971) that even without gel filtration yields highly homogeneous actin in purity greater than 90\%. CaATPG-actin was stored in a buffer containing $5 \mathrm{mM}$ Tris $\mathrm{HCl}$,
$0.2 \mathrm{mM} \mathrm{CaCl}_{2}, 0.2 \mathrm{mM}$ ATP, $0.5 \mathrm{mM} \beta$-mercaptoethanol, $\mathrm{pH}$ 8.0 (CaATP-G-buffer). MgF-actin was polymerized from CaATPG-actin by $30 \mathrm{~min}$ incubation with $2 \mathrm{mM} \mathrm{MgCl}_{2}$ at room temperature. MgF-actin was diluted for further treatments in MgF-buffer containing $5 \mathrm{mM}$ MOPS, $2 \mathrm{mM} \mathrm{MgCl}_{2}, 0.2 \mathrm{mM}$ ATP, and $0.5 \mathrm{mM}$ DTT, pH 7.4. The concentration of unlabeled rabbit skeletal muscle CaATP-G-actin and Mg-F-actin was determined spectrophotometrically using the extinction coefficients $\mathrm{E} 1 \%_{290}=11.5 \mathrm{~cm}^{-1}$. (The optical density of actin was measured in the presence of $0.5 \mathrm{M} \mathrm{NaOH}$, which shifts the maximum of absorbance from 280 to $290 \mathrm{~nm}$ ). Molecular mass of skeletal actin was assumed to be $42 \mathrm{kDa}$. Boiled actin: F-actin was heat-denaturated by incubated it in boiling water bath for $10 \mathrm{~min}$.

\section{Bacterial Strains and Growth Conditions}

Bacillus subtilis was used as test organism. Tough it is not a pathogen, its relative sensitivity to antimicrobial peptides makes it a preferred model organism to study the antimicrobial actions of antimicrobial peptides (Sol et al., 2014, 2015) and the effect of others molecules on the antimicrobial action of antimicrobial peptides.

Bacillus subtilis PY79 (a kind gift of Prof. S. Ben-Yehuda, Hebrew University, Jerusalem, Israel) and Pseudomonas aeruginosa PAO1 (from our laboratory stock) were grown in LB Broth (Difco) at $37^{\circ} \mathrm{C}$ under aerobic conditions. Porphyromonas gingivalis ATCC 33277 (from our laboratory stock) was grown in Wilkins Chalgren medium II, (Oxoid, UK) in anaerobic jars (Oxoid) at $37^{\circ} \mathrm{C}$. For supernatant collection, overnight cultures of $P$. aeruginosa and 4-day cultures of $P$. gingivalis were centrifuged at $20,000 \times g$ for $10 \mathrm{~min}$, and the supernatant was collected and transferred through a $0.2 \mu \mathrm{m}$ filter (BD Biosciences). Bacterial purity was determined by phase contrast microscopy.

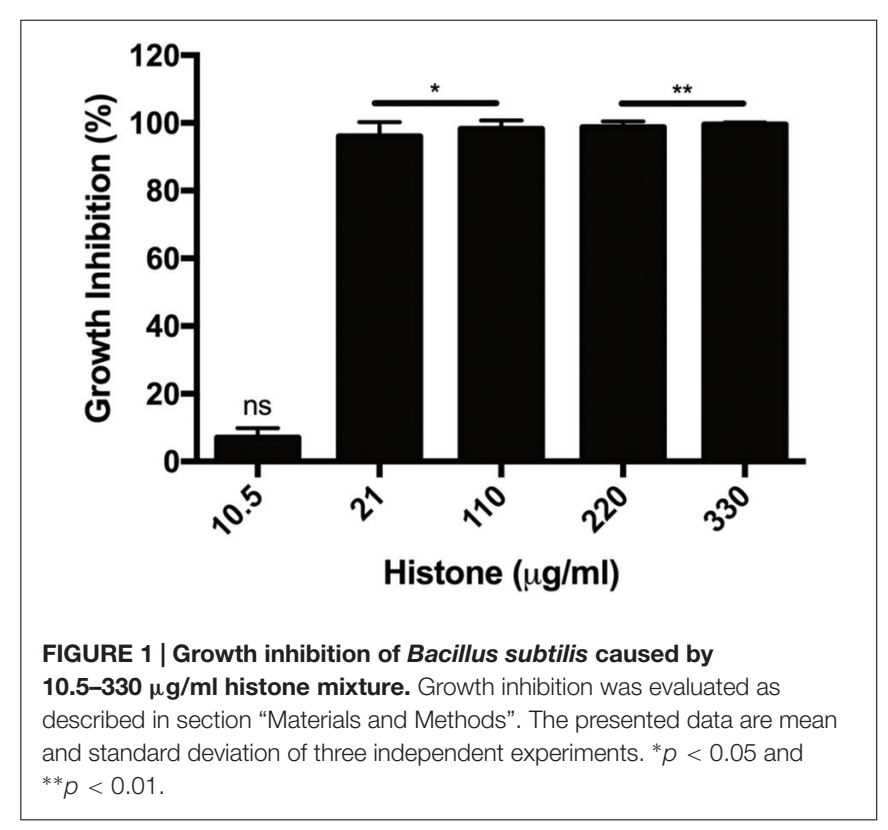



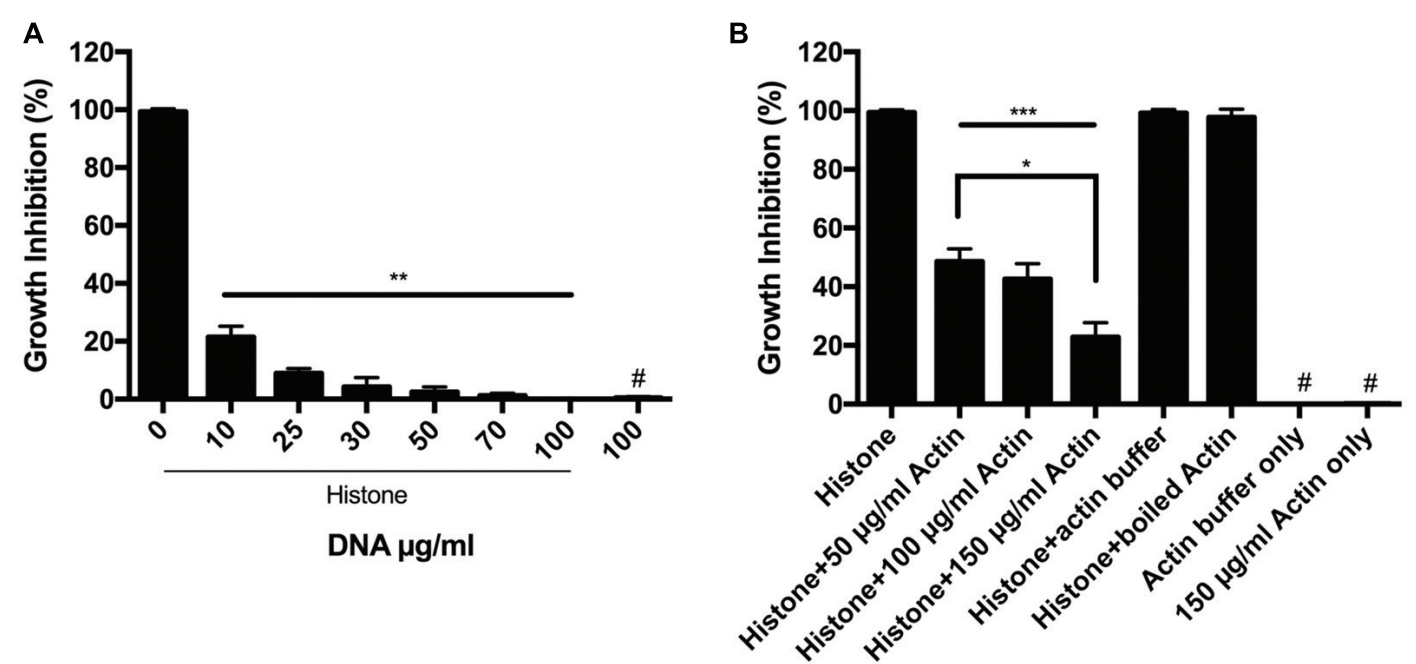

FIGURE 2 | Antimicrobial activity of histone in the presence of DNA and F-actin. (A) Effect of 10-100 $\mu \mathrm{g} / \mathrm{ml} \mathrm{DNA} \mathrm{(A)} \mathrm{or} \mathrm{50-150} \mu \mathrm{g} / \mathrm{ml} \mathrm{F-actin} \mathrm{(B)} \mathrm{on} \mathrm{the}$ growth inhibition of $B$. subtilis caused by $50 \mu \mathrm{g} / \mathrm{ml}$ histone mixture. Growth inhibition was measured as given in section "Materials and Methods". The presented data are mean and standard deviation of three independent experiments. ${ }^{*} p<0.05,{ }^{* *} p<0.01$, and ${ }^{* * *} p<0.005$. \# indicated no growth inhibition observed.

\section{Growth Inhibition Measurements and Protection Assay}

We first tested the antimicrobial activity of $10.5-330 \mu \mathrm{g} / \mathrm{ml}$ histone type III (histone mixture) by dilution of histone in final volume of $50 \mu \mathrm{l}$. The reaction mixtures were added to wells of 96-well plates (Nunc, Denmark) containing $150 \mu \mathrm{l}$ of B. subtilis PY79 cells (at mid-logarithmic growth diluted 1:5,000 in LB) to complete a $200 \mu \mathrm{l}$ final volume. For measuring bacterial growth inhibition activity of histone mixture, the plates were transferred to a GENIOS Microplate Reader (TECAN, Austria), and absorbance at $595 \mathrm{~nm}$ were measured during incubation at $37^{\circ} \mathrm{C}$ every $20 \mathrm{~min}$ (after automated mixing/aeration for $500 \mathrm{~s}$ ) to generate growth curves. Percent growth inhibition of each treatment was compared with growth at late logarithmic growth phase of untreated bacteria ( $0 \%$ growth inhibition, $\sim 10 \mathrm{~h}$ ). To test the effect of actin and DNA on the growth inhibition action of histones, histone mixture $(50 \mu \mathrm{g} / \mathrm{ml})$ were incubated with or without $50-150 \mu \mathrm{g} / \mathrm{ml} \mathrm{F}$-actin or $10-100 \mu \mathrm{g} / \mathrm{ml} \mathrm{DNA}$ for $10 \mathrm{~min}$ at $37^{\circ} \mathrm{C}$, then, $5 \mu \mathrm{l}$ of the protease-containing late logarithmic growth supernatant of $P$. gingivalis diluted 1:10 was added (or not) to the $50-\mu \mathrm{l}$ reaction mixture and incubated for $30 \mathrm{~min}$ at $37^{\circ} \mathrm{C}$. The reaction mixtures were added to wells of 96 -well plates (Nunc, Denmark) containing $150 \mu \mathrm{l}$ of B. subtilis PY79 cells and growth inhibition was measured as described above.

\section{Proteolytic Digestion and Densitometry}

Histone mixture $(42 \mu \mathrm{g} / \mathrm{ml}$ or $63 \mu \mathrm{g} / \mathrm{ml}$ ) was digested by $4 \mu \mathrm{l}$ of $10 \times$ diluted $P$. gingivalis or $10 \mu \mathrm{l}$ of $200 \times$ diluted $P$. aeruginosa supernatant, respectively. Samples incubated in the presence or absence of actin and DNA at $20^{\circ} \mathrm{C}$ for $30 \mathrm{~min}$. All constituents were added simultaneously, run on 12\% SDS PAGE, visualized by Coomassie Blue and evaluated by densitometry. Heat-denaturated $P$. gingivalis and $P$. aeruginosa supernatants were used as controls.

\section{Statistics}

Unless specified, all presented data are mean $\pm \mathrm{SD}$ of three independent experiments performed in triplicate. All presented SDS gels blots are representative of three independent experiments. Student's $t$-test was used for calculation of $p$ values.

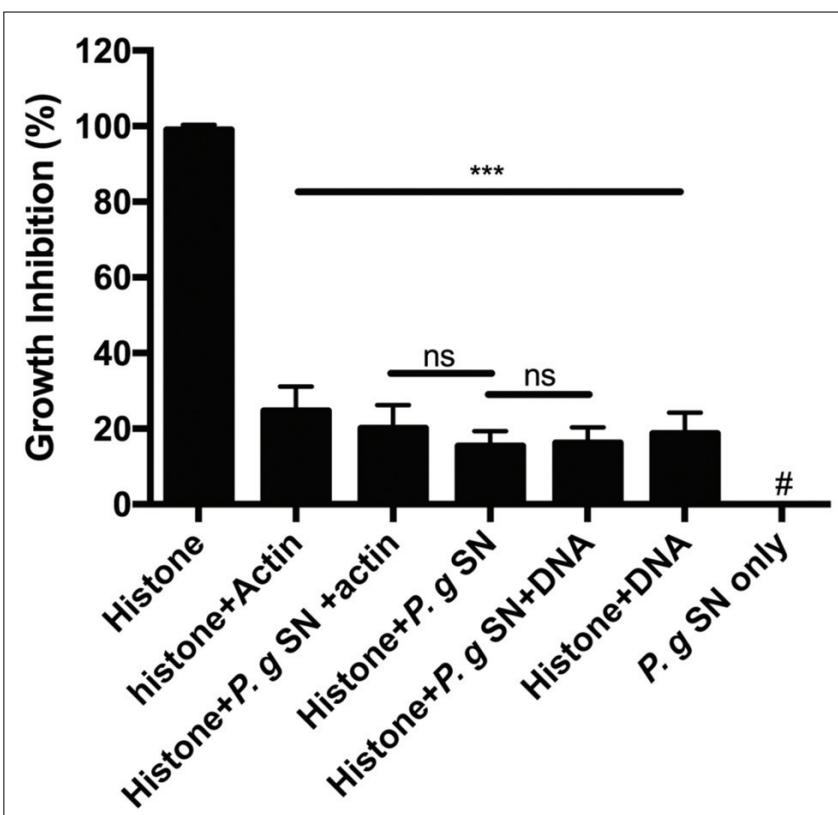

FIGURE 3 | Effect of $150 \mu \mathrm{g} / \mathrm{ml} \mathrm{F-actin,} 15 \mu \mathrm{g} / \mathrm{ml}$ DNA and digestion by 1:10 diluted Porphyromonas gingivalis supernatant (P.g. SN) on the growth inhibition of $B$. subtilis caused by $50 \mu \mathrm{g} / \mathrm{ml}$ histone mixture. Growth inhibition was measured as given in section "Materials and Methods". The presented data are mean and standard deviation of three independent experiments. ${ }^{* * *} p<0.005$. \# indicated no growth inhibition observed. 

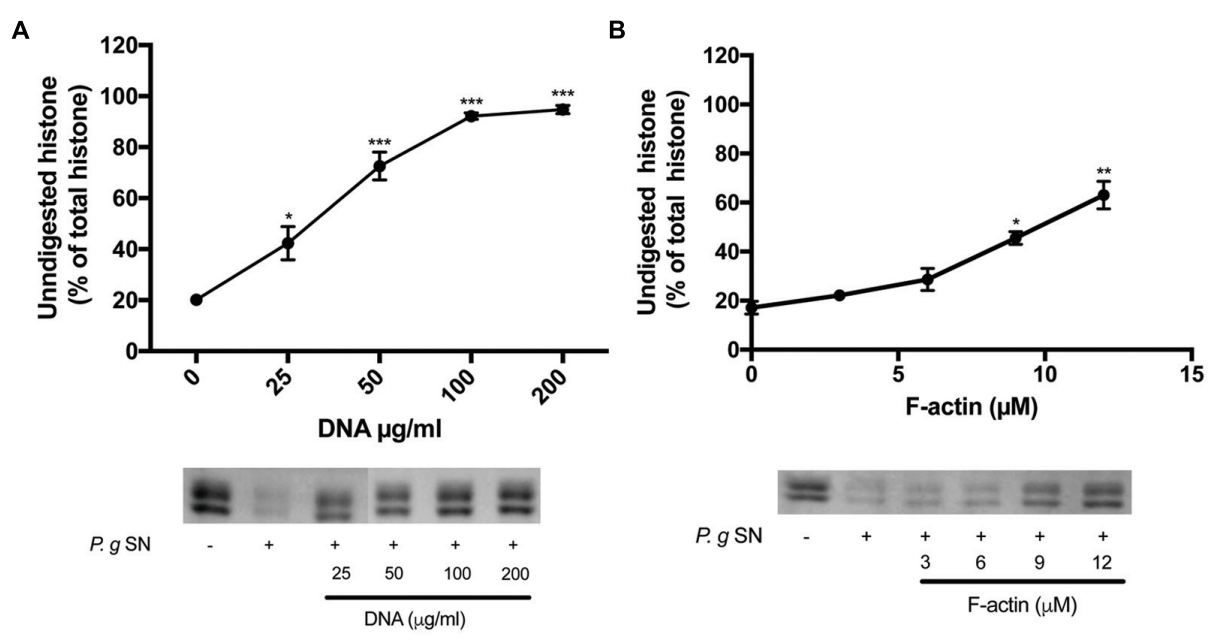

FIGURE 4 | Effect of DNA and F-actin on the digestion of histone mixture by $\boldsymbol{P}$ gingivalis proteases. Histone mixture (42 $\mu \mathrm{g} / \mathrm{ml})$ was digested by $4 \mu$ l of $\mathrm{P}$. $\mathrm{g}$ SN diluted 1:10 in the presence or absence of 0-200 $\mu \mathrm{g} / \mathrm{ml}$ DNA (A) or 0-12 $\mu$ M F-actin (B). The effect of DNA and F-actin on histone digestion was measured by calculating the undigested histone proportion in SDS-PAGE. Digestions were carried out at $20^{\circ} \mathrm{C}$ for 30 min, samples were run on SDS-PAGE and evaluated as described in section "Materials and Methods". The presented data are mean and standard deviation of three independent experiments. * $p<0.05$, ** $p<0.01$, and $* * * p<0.005$.

A

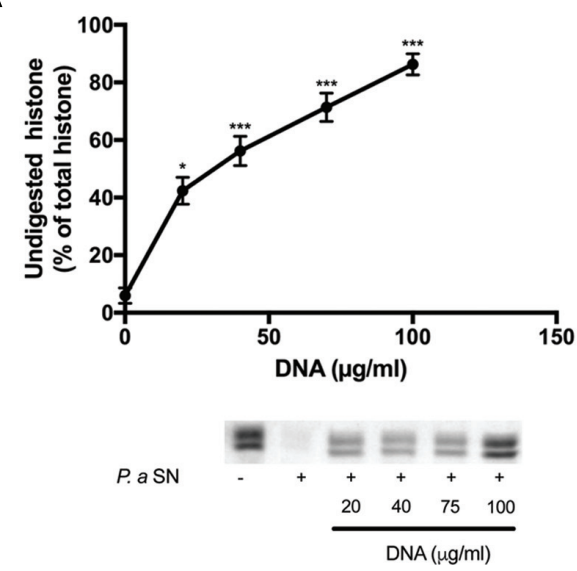

B

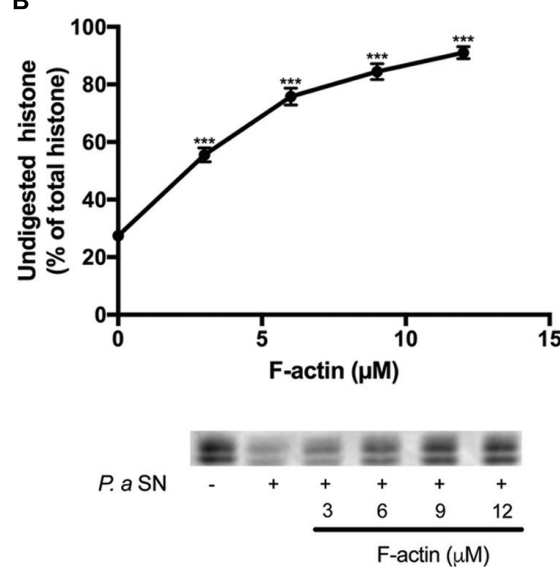

FIGURE 5 | Effect of DNA and F-actin on the digestion of histone mixture by $P$. aeruginosa proteases. Histone mixture $(63 \mu \mathrm{g} / \mathrm{ml})$ was digested by $10 \mu \mathrm{l}$ of 1:200 diluted $P$. aeruginosa supernatant in the presence or absence of $0-100 \mu \mathrm{g} / \mathrm{ml} \mathrm{DNA}$ (A) or 0-12 $\mu \mathrm{M}$ F-actin (B). The effect of DNA and F-actin on histone digestion was measured by calculating the undigested histone proportion in SDS-PAGE. Digestions were carried out at $20^{\circ} \mathrm{C}$ for $30 \mathrm{~min}$. Samples were run on SDS-PAGE and evaluated as described in section "Materials and Methods". The presented data are mean and standard deviation of three independent experiments. ${ }^{*} p<0.05$ and $^{* * *} p<0.005$

\section{RESULTS}

\section{Antibacterial Activity of Histone Mixture and Its Inhibition by DNA, F-actin, and Proteolysis}

Several extracellular histones were shown to possess antimicrobial activity. Here we measured the growth inhibition of $B$. subtilis by a histone mixture during 16-h incubation and found histone to be a potent inhibitor since already at $21 \mu \mathrm{g} / \mathrm{ml}$, bacterial growth was inhibited by $97 \%$ after $10 \mathrm{~h}$ incubation (Figure 1).
It is well known that DNA forms a very tight structured complex with histones in the cell nucleus. We, therefore, studied how purified DNA affects the antimicrobial activity of extracellular histone mixture (Figure 2A). We found that DNA abolishes the growth inhibition activity of the histone mixture in a concentration dependent manner. Moreover, the antimicrobial activity of a $50 \mu \mathrm{g} / \mathrm{ml}$ histone mixture decreased by $80 \%$ in the presence of $10 \mu \mathrm{g} / \mathrm{ml} \mathrm{DNA}$ and was completely abolished by $100 \mu \mathrm{g} / \mathrm{ml}$ DNA present during overnight incubation.

It was previously suggested that $\mathrm{H} 1$ could polymerize G-actin (Magri et al., 1978) and that histone H2A-H2B dimer 

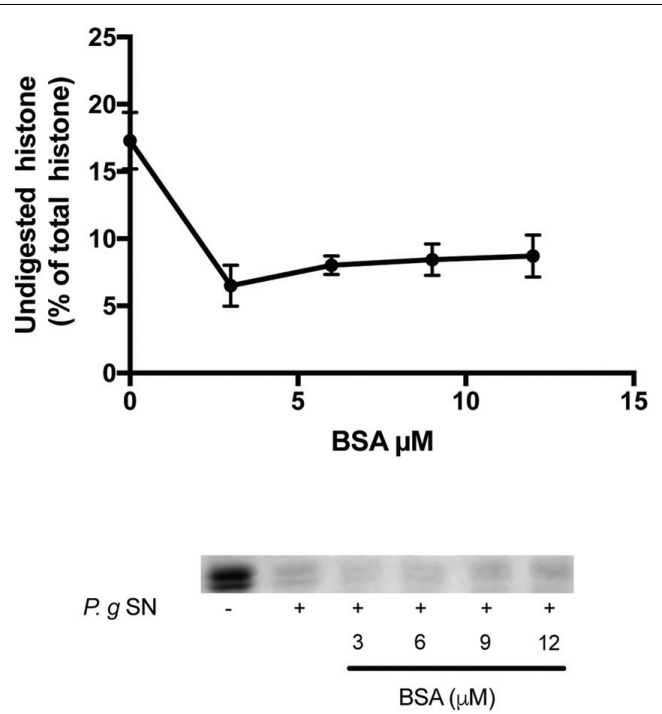

FIGURE 6 | Effect of bovine serum albumin (BSA) on the digestion of histone mixture by $\boldsymbol{P}$ gingivalis proteases. Histone mixture $(42 \mu \mathrm{g} / \mathrm{ml})$ was digested by $4 \mu$ l of 1:10 diluted $P$. gingivalis supernatant in the presence or absence of $0-12 \mu \mathrm{M}$ BSA. The effect of BSA on histone digestion was measured by calculating the undigested histone proportion in SDS-PAGE. Digestions were carried out at $20^{\circ} \mathrm{C}$ for $30 \mathrm{~min}$, samples were run on SDS-PAGE and evaluated as described in section "Materials and Methods". The presented data are mean and standard deviation of three independent experiments.

can mediate the bundling of F-actin (Doyle et al., 2011) demonstrating that the negatively charged actin interacts with the positively charged histones. We studied the effect of F-actin on the antimicrobial activity of histone mixture during overnight incubation (Figure 2B). 50-150 $\mu \mathrm{g} / \mathrm{ml} \mathrm{F-actin} \mathrm{was}$ found to decrease growth inhibition of $B$. subtilis challenged with a $50 \mu \mathrm{g} / \mathrm{ml}$ histone mixture by approximately $55-80 \%$, respectively. Actin buffer or $150 \mu \mathrm{g} / \mathrm{ml} \mathrm{F-actin} \mathrm{alone} \mathrm{without}$ histone did not affect the growth of B. subtilis (Figure 2B).

The antimicrobial activity of the histone mixture was inhibited by the supernatant of $P$. gingivalis (Figure 3 ). Upon addition of bacterial supernatant, the antimicrobial activity of $50 \mu \mathrm{g} / \mathrm{ml}$ histone mixture decreased by $85 \%$. This decrease is due to the proteolytic activity in the supernatant as shown by Figure 4. Unlike the cationic antimicrobial peptide LL-37 that was protected by actin from degradation with supernatant of $P$. gingivalis while retaining its antimicrobial activity (Sol et al., 2014), the presence of $150 \mu \mathrm{g} / \mathrm{ml}(3.6 \mu \mathrm{M})$ F-actin or $15 \mu \mathrm{g} / \mathrm{ml}$ DNA during the proteolysis did not enable the antimicrobial activity of the histone mixture. The growth-inhibition obtained in the presence of $P$. gingivalis supernatant and DNA or F-actin was very similar to the values obtained in the presence of DNA or F-actin alone.

\section{DNA and F-actin Protect Histone Mixture from Proteolysis by Bacterial Proteases}

As was showed above, both DNA and F-actin inhibit the antimicrobial activity of histones, which demonstrates their interactions with histones. Therefore, we wanted to determine whether the presence of DNA and F-actin can inhibit the proteolysis of histone mixture by proteolytic bacteria.

The supernatants of two pathogenic proteolytic bacteria, $P$. gingivalis and $P$. aeruginosa were used as protease sources for studying the proteolysis of the histone mixture (Figures 4 and 5). Histone proteolysis by the $P$. aeruginosa supernatant was much stronger than that by $P$. gingivalis as it was possible to dilute the former 200 times and still obtain about $90 \%$ digestion of the histone mixture while for $P$. gingivalis supernatant could be diluted only 10 times for the similar degree of digestion. Control heat inactivated $P$. gingivalis and $P$. aeruginosa supernatants did not digest histone mixture. Next, we attempted to digest $42 \mu \mathrm{g} / \mathrm{ml}$ of histone mixture by $10 \mathrm{X}$ diluted $P$. gingivalis supernatant in the absence or presence of $0-200 \mu \mathrm{g} / \mathrm{ml}$ DNA (Figure 4A), and $0-12 \mu \mathrm{M}$ F-actin, which corresponds to $126-504 \mu \mathrm{g} / \mathrm{ml}$ F-actin (Figure 4B). Both DNA and F-actin protected the histone mixture from proteolysis. However, DNA was a more efficient inhibitor, since $100 \mu \mathrm{g} / \mathrm{ml}$ DNA protected up to $90 \%$ of histone from degradation, while $504 \mu \mathrm{g} / \mathrm{ml} \mathrm{F}$-actin protected only up to $65 \%$ of the histone mixture from degradation. The digestion of $63 \mu \mathrm{g} / \mathrm{ml}$ histone mixture by $P$. aeruginosa supernatant was carried out under similar conditions as by $P$. gingivalis. Both DNA and F-actin significantly protected the histone mixture from proteolysis by $P$. aeruginosa. $100 \mu \mathrm{g} / \mathrm{ml}$ DNA (Figure 5A) or $504 \mu \mathrm{g} / \mathrm{ml} \mathrm{F-actin} \mathrm{(Figure} \mathrm{5B)} \mathrm{were} \mathrm{needed} \mathrm{for} \mathrm{decrease} \mathrm{the}$ amount of digested histone mixture to $\sim 10 \%$ of the total histone mixture present.

Finally, to see the specificity of the ability of F-actin to protect histone mixture against proteolysis, the effect of another protein, bovine serum albumin (BSA), on the digestion of histone mixture was studied (Figure 6). In this experiment $42 \mu \mathrm{g} / \mathrm{ml}$ histone mixture was digested by $10 \mathrm{X}$ diluted $P$. gingivalis supernatant in the presence of $0-12 \mu \mathrm{M}(0-780 \mu \mathrm{g} / \mathrm{ml})$ BSA. We found that the presence of BSA does not inhibit but accelerates the digestion of histone mixture. The results indicate that the proteolysis of a histone mixture by bacterial proteases is specifically protected by DNA and F-actin.

\section{DISCUSSION}

Histones are released from activated immune cells (e.g., neutrophils and mast cells) into extracellular traps (NETs) (Brinkmann et al., 2004; von Kockritz-Blickwede et al., 2008) in response to microbial infection. NETs are networks of extracellular fibers composed of DNA, core histones and other antimicrobial factors, which capture and inactivate invading microorganisms (Chen et al., 2014). In addition to NETosismediated histone release, apoptotic or necrotic cells can also release histones (Wickman et al., 2013). Histones possess a strong antimicrobial activity at surprisingly low concentrations (Figure 1), which protects the organism against invading microorganisms. However, release of large amounts of histone due to a severe bacterial infection can have dangerous deleterious effects on host since extracellular histones are cytotoxic (Ginsburg et al., 1993) and mediate a systemic inflammatory 
response syndrome including life threatening sepsis ( $\mathrm{Xu}$ et al., 2009).

Bacteria protect themselves against the strong antimicrobial activity of host defense peptides and histones using proteases, which degrade these protein-based immune factors. Polyanions, which are bound to polycationic histones (Ginsburg et al., 1993) may protect extracellular histones against the bacterial proteases. We found that polyanionic DNA, a very significant constituent of NETs, and F-actin, which is released into the extracellular space upon necrosis and cell death (Sol et al., 2014), might bind histones and inhibit their digestion by bacterial proteases (Figures 4 and 5). However, unlike the actin protection of the LL-37 antimicrobial peptide from bacterial degradation, the protection of histones against bacterial proteases by DNA and F-actin does not enable the antimicrobial action of histones. This because DNA and F-actin themselves strongly inhibit the bactericidal activity of histones (Figure 2).

The inhibition of the antimicrobial action of extracellular histones by DNA and F-actin has a physiological significance since the large amounts of histones released from the cells upon acute inflammation in addition to their beneficial bactericidal effect, could endanger the host because of their cytotoxicity. It seems that the proper equilibrium between the beneficial antimicrobial and the deleterious cytotoxic effects of extracellular histones, by their release in NETosis, apoptosis or from necrotic cells in on one side, and the inhibition of their action by DNA and F-actin and polyanions in general on the other side, is important for the host's health. The change of this balance by the sudden release of great amounts of histones without the release of adequate amount DNA and actin could lead to serious pathological consequences such as tissue injury and

\section{REFERENCES}

Allam, R., Kumar, S. V., Darisipudi, M. N., and Anders, H. J. (2014). Extracellular histones in tissue injury and inflammation. J. Mol. Med. (Berl.) 92, 465-472. doi: 10.1007/s00109-014-1148-Z

Brinkmann, V., Reichard, U., Goosmann, C., Fauler, B., Uhlemann, Y., Weiss, D. S., et al. (2004). Neutrophil extracellular traps kill bacteria. Science 303, 1532-1535. doi: 10.1126/science 1092385

Brockson, M. E., Novotny, L. A., Mokrzan, E. M., Malhotra, S., Jurcisek, J. A., Akbar, R., et al. (2014). Evaluation of the kinetics and mechanism of action of anti-integration host factor-mediated disruption of bacterial biofilms. Mol. Microbiol. 93, 1246-1258. doi: 10.1111/mmi.12735

Chaput, C., and Zychlinsky, A. (2009). Sepsis: the dark side of histones. Nat. Med. 15, 1245-1246. doi: 10.1038/nm1109-1245

Chen, R., Kang, R., Fan, X. G., and Tang, D. (2014). Release and activity of histone in diseases. Cell Death Dis. 5:e1370. doi: 10.1038/cddis.2014.337

Cho, J. H., Sung, B. H., and Kim, S. C. (2009). Buforins: histone H2A-derived antimicrobial peptides from toad stomach. Biochim. Biophys. Acta 1788, 15641569. doi: 10.1016/j.bbamem.2008.10.025

Doyle, A., Crosby, S. R., Burton, D. R., Lilley, F., and Murphy, M. F. (2011). Actin bundling and polymerisation properties of eukaryotic elongation factor 1 alpha (eEF1A), histone H2A-H2B and lysozyme in vitro. J. Struct. Biol. 176, 370-378. doi: 10.1016/j.jsb.2011.09.004

Estelles, A., Woischnig, A. K., Liu, K., Stephenson, R., Lomongsod, E., Nguyen, D., et al. (2016). A high-affinity native human antibody disrupts biofilm from Staphylococcus aureus bacteria and potentiates antibiotic efficacy in a mouse implant infection model. Antimicrob. Agents Chemother. 60, 2292-2301. doi: 10.1128/AAC.02588-2515 inflammation (Allam et al., 2014) and the development of fatal sepsis.

Bacteria have DNA binding proteins that resemble histones (DNABII). These proteins which include the integration host factor (IHF) have gene-expression regulatory functions but also an extracellular important role in biofilm formation. Through interactions with extracellular DNA they form a network that is part of the biofilm matrix (Brockson et al., 2014). Among the bacteria that are dependent on IHF for biofilm formation is $P$. aeruginosa. Antibodies that block IHF, greatly impaired biofilm development by $P$. aeruginosa (Estelles et al., 2016). Being proteolytic bacteria which degrades histone (Figure 5), the question arises how IHF is not cleaved by the proteases of $P$. aeruginosa? Our results suggest that DNA might protect IHF from self-cleavage by $P$. aeruginosa.

\section{AUTHOR CONTRIBUTIONS}

AS, designed and carried out experiments, participated in writing the ms; YS, carried out experiments; EB, carried out experiments; $\mathrm{GB}$, designed experiments, and participated in writing $\mathrm{ms}$; AM, designed and carried out experiments and participated in writing ms.

\section{FUNDING}

This work was supported by Israel Science Foundation Grant $201 / 15$.

Ginsburg, I., Mitra, R. S., Gibbs, D. F., Varani, J., and Kohen, R. (1993). Killing of endothelial cells and release of arachidonic acid. Synergistic effects among hydrogen peroxide, membrane-damaging agents, cationic substances, and proteinases and their modulation by inhibitors. Inflammation 17, 295-319. doi: 10.1007/BF00918992

Hirsch, J. G. (1958). Bactericidal action of histone. J. Exp. Med. 108, 925-944. doi: 10.1084/jem.108.6.925

Jang, J. H., Kim, M. Y., Lee, J. W., Kim, S. C., and Cho, J. H. (2011). Enhancement of the cancer targeting specificity of buforin IIb by fusion with an anionic peptide via a matrix metalloproteinases-cleavable linker. Peptides 32, 895-899. doi: 10.1016/j.peptides.2011.02.010

Katchalski, E., Bichovski-Slomnitzki, L., and Volcani, B. E. (1952). Action of some water-soluble poly-a-amino-acids on bacteria. Nature 169, 1095-1096. doi: $10.1038 / 1691095 b 0$

Kawasaki, H., and Iwamuro, S. (2008). Potential roles of histones in host defense as antimicrobial agents. Infect. Disord. Drug Targets 8, 195-205. doi: $10.2174 / 1871526510808030195$

Kawasaki, H., Koyama, T., Conlon, J. M., Yamakura, F., and Iwamuro, S. (2008). Antimicrobial action of histone $\mathrm{H} 2 \mathrm{~B}$ in Escherichia coli: evidence for membrane translocation and DNA-binding of a histone H2B fragment after proteolytic cleavage by outer membrane proteinase T. Biochimie 90, 1693-1702. doi: 10.1016/j.biochi.2008.07.003

Koren, E., and Ginsburg, I. (2015). Synergistic aspects to explain the pathophysiology of sepsis and septic shock-an opinion. J. Infect. Dis. Ther. 3:254. doi: 10.4172/2332-0877.1000254

Lee, D. Y., Huang, C. M., Nakatsuji, T., Thiboutot, D., Kang, S. A., Monestier, M., et al. (2009). Histone H4 is a major component of the antimicrobial action of human sebocytes. J. Invest. Dermatol. 129, 2489-2496. doi: 10.1038/jid.2009.106 
Lee, H. S., Park, C. B., Kim, J. M., Jang, S. A., Park, I. Y., Kim, M. S., et al. (2008). Mechanism of anticancer activity of buforin IIb, a histone $\mathrm{H} 2 \mathrm{~A}$-derived peptide. Cancer Lett. 271, 47-55. doi: 10.1016/j.canlet.2008.05.041

Magri, E., Zaccarini, M., and Grazi, E. (1978). The interaction of histone and protamine with actin. Possible involvement in the formation of the mitotic spindle. Biochem. Biophys. Res. Commun. 82, 1207-1210. doi: 10.1016/0006291X(78)90315-7

Muhlrad, A., Grintsevich, E. E., and Reisler, E. (2011). Polycation induced actin bundles. Biophys. Chem. 155, 45-51. doi: 10.1016/j.bpc.2011.02.008

Richards, R. C., O’Neil, D. B., Thibault, P., and Ewart, K. V. (2001). Histone H1: an antimicrobial protein of Atlantic salmon (Salmo salar). Biochem. Biophys. Res. Commun. 284, 549-555. doi: 10.1006/bbrc.2001.5020

Robinette, D., Wada, S., Arroll, T., Levy, M. G., Miller, W. L., and Noga, E. J. (1998). Antimicrobial activity in the skin of the channel catfish Ictalurus punctatus: characterization of broad-spectrum histone-like antimicrobial proteins. Cell. Mol. Life Sci. 54, 467-475. doi: 10.1007/s000180050175

Rottner, K., and Stradal, T. E. (2011). Actin dynamics and turnover in cell motility. Curr. Opin. Cell Biol. 23, 569-578. doi: 10.1016/j.ceb.2011.07.003

Sathyan, N., Philip, R., Chaithanya, E. R., Anil Kumar, P. R., Sanjeevan, V. N., and Singh, I. S. B. (2013). Characterization of histone H2A derived antimicrobial peptides, Harriottins, from Sicklefin Chimaera Neoharriotta pinnata (Schnakenbeck, 1931) and Its evolutionary divergence with respect to CO1 and histone H2A. ISRN. Mol. Biol. 2013, 1-10. doi: 10.1155/2013/930216

Sol, A., Blotnick, E., Bachrach, G., and Muhlrad, A. (2012). LL-37 induces polymerization and bundling of actin and affects actin structure. PLoS ONE 7:e50078. doi: 10.1371/journal.pone.0050078

Sol, A., Skvirsky, Y., Nashef, R., Zelentsova, K., Burstyn-Cohen, T., Blotnick, E., et al. (2014). Actin enables the antimicrobial action of LL-37 peptide in the presence of microbial proteases. J. Biol. Chem. 289, 22926-22941. doi: 10.1074/jbc.M114.579672

Sol, A., Wang, G., Blotnick, E., Golla, R., Bachrach, G., and Muhlrad, A. (2015). Interaction of the core fragments of the LL-37 host defense peptide with actin. RSC Adv. 5, 9361-9367. doi: 10.1039/C4RA13007C

Spudich, J. A., and Watt, S. (1971). The regulation of rabbit skeletal muscle contraction. I. Biochemical studies of the interaction of the tropomyosintroponin complex with actin and the proteolytic fragments of myosin. J. Biol. Chem. 246, 4866-4871.
Tagai, C., Morita, S., Shiraishi, T., Miyaji, K., and Iwamuro, S. (2011). Antimicrobial properties of arginine- and lysine-rich histones and involvement of bacterial outer membrane protease $\mathrm{T}$ in their differential mode of actions. Peptides 32, 2003-2009. doi: 10.1016/j.peptides.2011. 09.005

von Kockritz-Blickwede, M., Goldmann, O., Thulin, P., Heinemann, K., Norrby-Teglund, A., Rohde, M., et al. (2008). Phagocytosis-independent antimicrobial activity of mast cells by means of extracellular trap formation. Blood 111, 3070-3080. doi: 10.1182/blood-2007-07104018

Wickman, G. R., Julian, L., Mardilovich, K., Schumacher, S., Munro, J., Rath, N., et al. (2013). Blebs produced by actin-myosin contraction during apoptosis release damage-associated molecular pattern proteins before secondary necrosis occurs. Cell Death Differ. 20, 1293-1305. doi: 10.1038/cdd. 2013.69

Williamson, W. D., and Pinto, I. (2012). Histones and genome integrity. Front. Biosci. (Landmark Ed.) 17:984-995. doi: 10.2741/3969

Wu, D., Ingram, A., Lahti, J. H., Mazza, B., Grenet, J., Kapoor, A., et al. (2002). Apoptotic release of histones from nucleosomes. J. Biol. Chem. 277, 1200112008. doi: 10.1074/jbc.M109219200

Xu, J., Zhang, X., Pelayo, R., Monestier, M., Ammollo, C. T., Semeraro, F., et al. (2009). Extracellular histones are major mediators of death in sepsis. Nat. Med. 15, 1318-1321. doi: 10.1038/nm.2053

Xu, Z., Huang, Y., Mao, P., Zhang, J., and Li, Y. (2015). Sepsis and ARDS: the dark side of histones. Mediators Inflamm. 2015:205054. doi: 10.1155/2015/205054

Conflict of Interest Statement: The authors declare that the research was conducted in the absence of any commercial or financial relationships that could be construed as a potential conflict of interest.

Copyright (c) 2016 Sol, Skvirsky, Blotnick, Bachrach and Muhlrad. This is an openaccess article distributed under the terms of the Creative Commons Attribution License (CC BY). The use, distribution or reproduction in other forums is permitted, provided the original author(s) or licensor are credited and that the original publication in this journal is cited, in accordance with accepted academic practice. No use, distribution or reproduction is permitted which does not comply with these terms. 